\title{
LEADERSHIP AND TEAM PERFORMANCE AS DEVELOPMENT TOOL FOR CREATING SUSTAINABLE EDUCATION
}

\author{
Anna Kvelde \\ RISEBA, Latvia
}

\begin{abstract}
Team performance is important at work and in organizational psychology as it aims to promote human energy. The human energy is more than just a "New Age" concept, it has a substantial and predictable effect on performance and innovation in organizations. The aim of the study is to examine relations between leadership style and team performance and mediating role is played by the productive organizational energy. The study is based on literature and quantitative and qualitative research methods. A theoretical framework is assessed in the empirical study in Latvian organizations in 2019. The study was accomplished in co-operation with America company "The Energy Project" and the University of Arizona. The article reveals the model of human energy as a scientifically-based approach and transformational leadership as a development tool, which already has spread in all sectors of western societies, including educational organizations. The materials and recommendations can be used to assist organizations in identifying practices, processes and initiatives, which can have a positive impact on team performance and organizational energy. The general conclusion is that the transformation leadership lays a positive dynamic in the development of the team performance for sustainable education. The educational organizations can progress productive performance and create sustainable education in a particular manner by focusing on their human resources; considering their growth, development and well-being.
\end{abstract}

Keywords: productive team performance, sustainable education, transformational leadership.

\section{Introduction}

At the present stage of development of education, teachers are technologyoriented and responsible not only for teaching but also for the organization of students learning, as a result, increased stressful situations, work long hours and are tethered to work through technology. For the last decade have been extensively studied the symptoms of teacher's stress contributing to burnout (Helou \& Nabhani, 2016; Jacobson, 2016). Referring to the research conducted by A. Leme and I. Maia (2015) were deduced that teachers feel depleted with little personal human energy for family or community activities; teachers' fatigue causes motivation and well-being reduction and as a result, the increasingly poor performance. 
These issues together defined the problem of the study, which is to improve teacher's well-being and work-related performance. Referring to the analysis of the initial facts and the problem were highlighted the innovative topics of research: firstly, the ability to maintain personal human energy and to use it correctly for leadership at the workplace; secondly, the capacity to build new communication methods and to make use of relational energy, that should become an essential tool for managing the pedagogical process and improving productive team performance for sustainable education.

Interest in personal human energy flourished in the 1970s when H.J. Freudenberger (1975) became interested in burnout, mental fatigue, and mental distancing from work. At the beginning of 21st century, more attention is being paid to the study of positive social interactions for optimal human functioning and these lead scholars (Luthans \& Avolio, 2009) to prove the influential role of the human energy on individual and organizational level. The scientists A. Carmeli and G.M. Spreitzer (2009) confirmed that the human energy as resource demonstrate positive outcomes including performance and creativity, and emphasize that one of the key roles in the successful development of team performance is occupied by leader' behaviours.

The human energy resources had influenced the birth of transformational leadership theory, and this theory used to describe the ideal situation between leaders and followers (Bass, 1998). According to S.S. Khumalo (2019), transformational leadership style views relationship development as a crucial component of the work of educational institutions. It should be noted that through the implementation of transformational leadership in education, teachers and principals can influence school members to create learning conditions that activate the natural curiosity, interest, and motivation in students (Adams, Olsen, \& Ware, 2017), and, also, sustain the excellence, quality and high performance from subordinates and followers (Khumalo, 2019).

Sustainable education is currently considered a key factor in the development of the education system (Simane, 2019), in this study, the role of transformational leadership is used to prove the importance of contributing towards sustainable team performance and organizational productivity. The analysis of literature and results of empirical practice has allowed concluding that transformational leadership can become a development tool for creating sustainable education.

The aim of the study is to examine relations between leadership style and team performance and mediating role is played by the productive organizational energy. The research is based on literature and quantitative and qualitative research methods. 
SOCIETY. INTEGRATION. EDUCATION

Proceedings of the International Scientific Conference. Volume VI, May $28^{\text {th }}-29^{\text {th }}$, 2021. 336-346

\section{Literature Review}

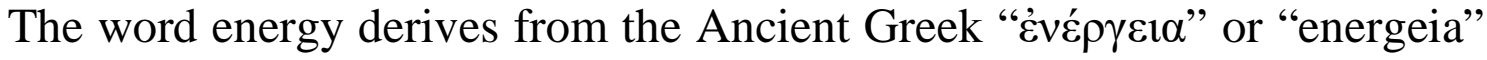
that's mean 'activity, operation', which appears for the first time in the work of Aristotle in the 4th century BC, it described qualitative philosophical concept, which fuels one's potentiality (Burn, 1978). Important to mention that in Eastern philosophy " $Q i$ '" (life power or energy flow) is a concept that is often mentioned concerning physical and mental health, but in Western philosophy and theory, it remains more unexplored. In the study, the human energy definition is used from Lexico, Oxford Dictionary (2019) with meaning as "the strength and vitality required for sustained physical or cognitive activity”.

The scientists B. Rich, J. LePine and E.R. Crawford (2010) in their study emphasized that human energy is one operative and defining characteristic of work engagement. The study of R. Ryan and C. Frederick (1997) has indeed shown a positive relationship between the human energy and vitality and wellbeing, also helps people regulate their behaviours and emotions in compliance with organizational or group norms and expectations.

Three kinds of human energy dimensions are discerned:

1. mental and spiritual energy (being able to intensely focus) (Baker, 2019);

2. physical energy (strength, endurance, flexibility) (Baker, 2019);

3. emotional energy/ relation energy (being in touch with feelings and core values) (Baker, 2019).

W.E. Baker (2019) suggested altered category labelled "emotional" energy to "relational" energy, also, has identified the powerful role that the relational human energy play in corporate behaviour. The research about the relational human energy reported that it has enclosed high-quality relationships at work, generate and sustain energetic resources, motivate people to do work well and positively associated with team performance (Baker, 2019).

The analysis of literature has allowed concluding that human energy resources had influenced the birth of transformational leadership theory. B.M. Bass (1998) described transformational leadership in terms of the impact that it has on followers, as it is created around the idea of leading by example. Transformational leadership influence follower and enable them, to generate psychological empowerment of a person as a result of interaction between a characteristic of the individual and organization environment, including the leader-follower relationship (Bass, 1998). Transformational leaders articulate a vision for the future, act as charismatic role models, set high-performance expectations, provide individualized support, and stimulate followers. In the study components of the framework for transformational leadership are specified, considered them as behaviours (Luthans \& Avolio, 2009). Transformational leadership has been found to be related: to follower performance, to job 
satisfaction, to organisational commitment (Schwartz, Gomez, \& McCarthy, 2010).

It should be noted that the research about the school experiences of future teachers highlighted the importance to establish a close and solid relationship between the teacher and the student, which is developed through a mutual desire to communicate and cooperate in the educational institution as an exceptional component of pedagogical professional activity (Masiliauskienè \& Lenkauskaite, 2020). Transformational leadership can be used by principals and teachers, as it places a high value on creating community bonds, encourages school members to greater levels of achievement, and to expand and grow in a nurturing community. One of the strengths of the transformational leadership is that it builds on the resources of every member of the school, particularly staff, teachers and students (Khumalo, 2019). The benefits of implementation of transformational leadership: (1) fosters a community that is committed to the goals of the school and the success of students, (2) provides intellectual stimulation, offers individualizes support, models best practices and value, demonstrates high-performance expectations and creates a productive teaching culture; (3) provides an environment that fosters the creation of new and innovative instructional techniques (Leithwood, Tomlinson, \& Genge, 1996; Adams, Olsen, \& Ware, 2017).

The researchers (Eisenberg, Ignatjeva, Iliško, \& Rauckiene-Michaelsso, 2018) describe transformational leadership as increasing the motivation of the team to achieve higher performance and as developing and the commitment and beliefs in the organization. The results of the study revealed that transformational leadership had a direct impact on team performance, organizational productivity and sustainability (Eisenberg et al., 2018). The implications of this study for management and organizational psychologist practitioners lies in developing organizational sustainability, by paying attention to the transformational leadership of their leaders.

The model of "Human Energy in Organizations" (HEO) is a scientificallybased approach to energizing people physically, emotionally, mentally and spiritually so they can perform sustainably at their best is explained. The model consists of four interrelated components: human energy, transformational leadership, productive team energy and productive organizational energy. The main basic components of HEO model are the human energy and transformational leadership, consolidation of them leads to a productive team and organizational energy (Figure 1). 


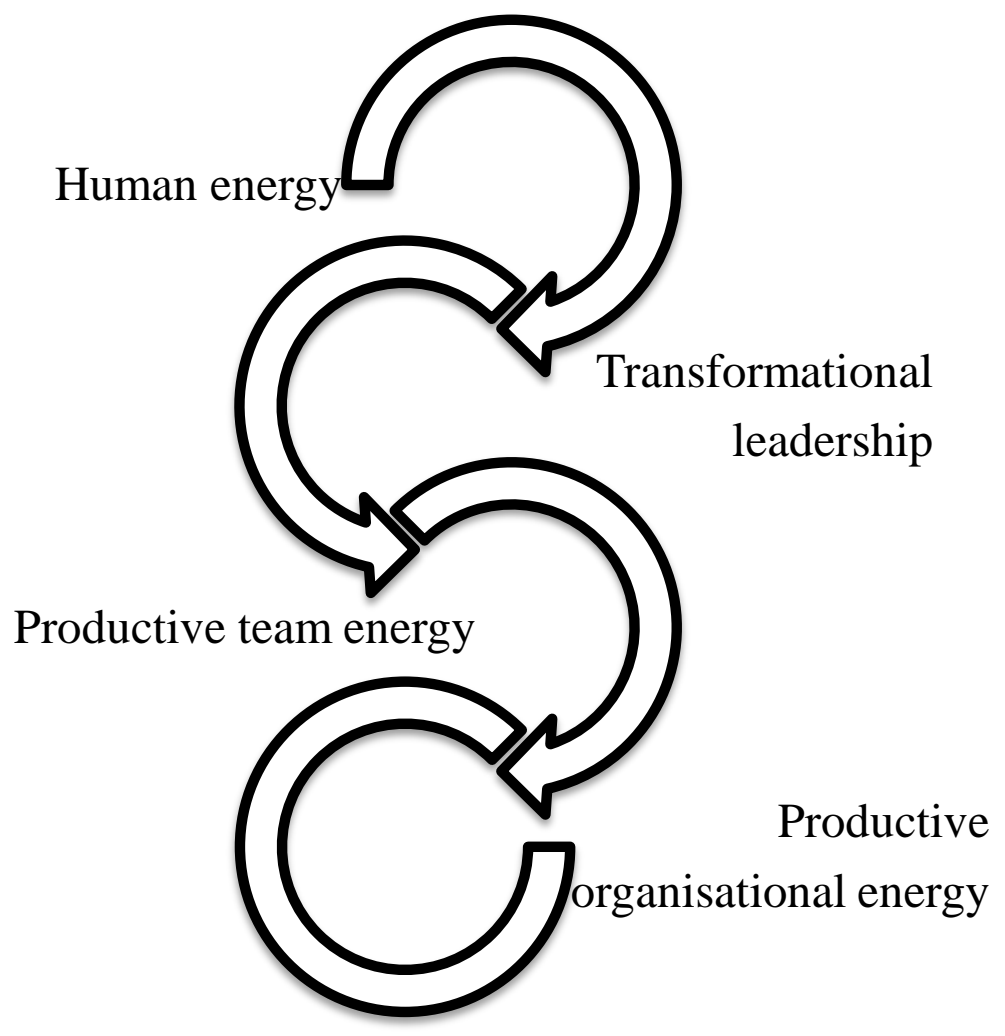

Figure 1 Model of Human Energy in Organization (developed by the author)

The researchers T. Schwartz, J. Gomez and C. McCarthy (2010) points out the great importance of productive team energy, they state that it integrates personal and relation human energy into four dimensions - mindset, culture, structure and behaviour, and it is an effective helping system for successful organizational transformation. In the summary of the HEO model are explained the last component - productive organizational energy (POE), it is described as the shared experience and demonstration of positive affect and behaviors among followers in their joint pursuit of organizationally salient objectives (Cole, Bruch, \& Vogel, 2008). POE is linked to such critical organizational aspects as well-being, internal effectiveness, organizational performance (Kenny \& Nnamdi, 2019)

\section{Methodology}

The aim of the empirical study is to examine the effect of transformational leadership on productive organization energy and the mediating role is played by the productive organizational energy. A mediating variable or "mediator" is an integral part of a cause-and-effect relationship. It makes it easier to understand how the independent variable is 
affecting the dependent variable and what is governing that relationship (Swaen, 2015).

Research questions: (1) Which aspects of transformational leadership relate relate to higher productive organisational energy and team performance? (2) How How organizational energy relates to team performance? (3) Which development development behaviours of transformational leadership can create and sustain productive organisation energy and team performance?

Methods of data collection: (1) questionnaire (2) observation (3) interview (4) case studies.

The population of the research consisted of 10 public and private organizations, which include 4 educational organization. Research object: leaders with 10 years' experience and their teams. The research focused on the perception of followers and leaders. The research made use of stratified sample type. For research has been examining respondents, a convenience sample, was taken from a diverse group of learners/employees of various organizations in Latvia. Respondents of this sample were females (56\%) and male (44\%). Most of the respondents are organizational teachers/managers in different departments (74\%), employed for 0-10 years in their company (85\%), work experience of 0-10 years (54\%) and work experience of $10-20$ years (46 \%).

\section{Research Instrument and Measures:}

1. Leaders survey content has 4 parts: Personal Information, The Multifactor Leadership Questionnaire (MLQ) (Rowold, 2005), Team performance (Sun, Xu, \& Shang, 2014), Productive Organizational Energy (Cole, Bruch, \& Vogel, 2008).

2. Followers survey content has 4 parts: Personal Information, Productive Organizational Energy, Team Performance; The Subjective Vitality (Ryan \& Frederick, 1997).

\section{Research Results}

Research Question 1: Which aspects of transformational leadership relate to higher productive organizational energy and team performance?

The research was aimed to analyse the positive impact of different leadership behaviours and factors on productive organization energy and team performance. The MLQ consisted of 7 leadership factors, with 3 different leadership behaviours. The research presents the correlation coefficients of all leadership aspects in relations to POE and team performance as evaluated by followers, to answer the first research question (Table 1). 
SOCIETY. INTEGRATION. EDUCATION

Proceedings of the International Scientific Conference. Volume VI, May $28^{\text {th }}-29^{\text {th }}$, 2021. 336-346

Table 1 The Correlation Coefficients of Leader`s Behaviours with Productive Organizational Energy and Team Performance (developed by the author)

\begin{tabular}{|c|c|c|c|c|}
\hline Nr. & $\begin{array}{l}\text { Leadership } \\
\text { factors }\end{array}$ & Leadership behaviours (LEB) & $\begin{array}{l}\text { POE } \\
\text { followers }\end{array}$ & $\begin{array}{c}\text { Team } \\
\text { Performance } \\
\text { followers }\end{array}$ \\
\hline 1. & \multirow{3}{*}{$\begin{array}{l}\text { F:1 } \\
\text { Idealised } \\
\text { influence }\end{array}$} & I make others feel good to be around me & -.12 & -.06 \\
\hline 8. & & Others have complete faith in me & .07 & .06 \\
\hline 15. & & \begin{tabular}{|l|} 
Others are proud to be associated with me. \\
\end{tabular} & .29 & -.13 \\
\hline 2. & \multirow{3}{*}{$\begin{array}{l}\text { F2: } \\
\text { Inspirational } \\
\text { motivation }\end{array}$} & $\begin{array}{l}\text { I express with a few simple words what we } \\
\text { could and should do }\end{array}$ & -.03 & $.0,8$ \\
\hline 9. & & $\begin{array}{l}\text { I provide appealing images about what we } \\
\text { can do }\end{array}$ & .15 & -.13 \\
\hline 16. & & I help others find meaning in their work. & .09 & .21 \\
\hline 3. & \multirow{3}{*}{$\begin{array}{l}\text { F3: Intellectual } \\
\text { stimulation }\end{array}$} & $\begin{array}{l}\text { I enable others to think about old problems } \\
\text { in new ways }\end{array}$ & .14 & -.27 \\
\hline 10. & & $\begin{array}{l}\text { I provide others with new ways of looking at } \\
\text { puzzling things. }\end{array}$ & -.13 & -.09 \\
\hline 17. & & $\begin{array}{l}\text { I get others to rethink ideas that they had } \\
\text { never questioned before }\end{array}$ & .14 & .36 \\
\hline 4. & \multirow{3}{*}{$\begin{array}{l}\text { F4: Individual } \\
\text { consideration }\end{array}$} & I help others develop themselves & .35 & .07 \\
\hline 11. & & I let others know how I think they are doing. & -.04 & -.11 \\
\hline 18. & & $\begin{array}{l}\text { I give personal attention to others who seem } \\
\text { rejected }\end{array}$ & -.24 & -.19 \\
\hline 5. & \multirow{3}{*}{$\begin{array}{l}\text { F5: } \\
\text { Contingent } \\
\text { reward }\end{array}$} & $\begin{array}{l}\text { I tell others what to do if they want to be } \\
\text { rewarded for their work. }\end{array}$ & .26 & -.05 \\
\hline 12. & & $\begin{array}{|ll|}\text { I provide recognition/rewards when } \\
\text { others reach their goals }\end{array}$ & .25 & -.04 \\
\hline 19. & & $\begin{array}{l}\text { I call attention to what others can get for } \\
\text { what they accomplish }\end{array}$ & .22 & -.01 \\
\hline 6. & \multirow{3}{*}{$\begin{array}{l}\text { F6: } \\
\text { Management } \\
\text { by exception }\end{array}$} & $\begin{array}{l}\text { I am satisfied when others meet agreed-upon } \\
\text { standards }\end{array}$ & .07 & .06 \\
\hline 13. & & $\begin{array}{l}\text { As long as things are working, I do not try to } \\
\text { change anything. }\end{array}$ & .05 & -.25 \\
\hline 20. & & $\begin{array}{l}\text { I tell others the standards they have to } \\
\text { know to carry out their work. }\end{array}$ & -.04 & .21 \\
\hline 7. & \multirow{3}{*}{$\begin{array}{l}\text { F7: } \\
\text { Laissez-faire } \\
\text { leadership }\end{array}$} & $\begin{array}{l}\text { I am content to let others continue working } \\
\text { in the same ways always. }\end{array}$ & -.09 & .07 \\
\hline 14. & & Whatever others want to do is OK with me & -1.2 & -.12 \\
\hline 21. & & $\begin{array}{l}\text { I ask no more of others than what is } \\
\text { absolutely essential. }\end{array}$ & .21 & .15 \\
\hline
\end{tabular}


According to the data, the recommended leader's behaviours related to higher POE and team performance as perceived by followers are pointed with bold. There is a significant positive correlation between leadership behaviours and higher POE and team performance as perceived by followers: $L E B 4 r=0.35$; LEB5 $r=0.26$; LEB12 $r=0.25$; LEB15 $r=0.25$; LEB16 $r=0.21$; LEB17 $r=0.36$; $L E B 19 r=0.22$; LEB20 $r=0.21$; LEB $21 r=0.21$.

In contrast, not recommended leaders ` behaviours related to lower POE and team performance are those who have significant negative correlation and are pointed in italic in Table 1 . There is significant negative correlation between behaviours LEB3 $r=-0,27$; LEB13 $r=-0,25$, LEB18 $r=-0,24$.

Only one leadership factor has all positive POE correlations, it is "Contingent reward". The contingent reward system is a motivation-based approach that is used to reward employees that meet their identified goals and provides positive reinforcement for a job well done (Whetten, Cameron, 2002).

Research Question 2: How productive organizational energy relates to team performance?

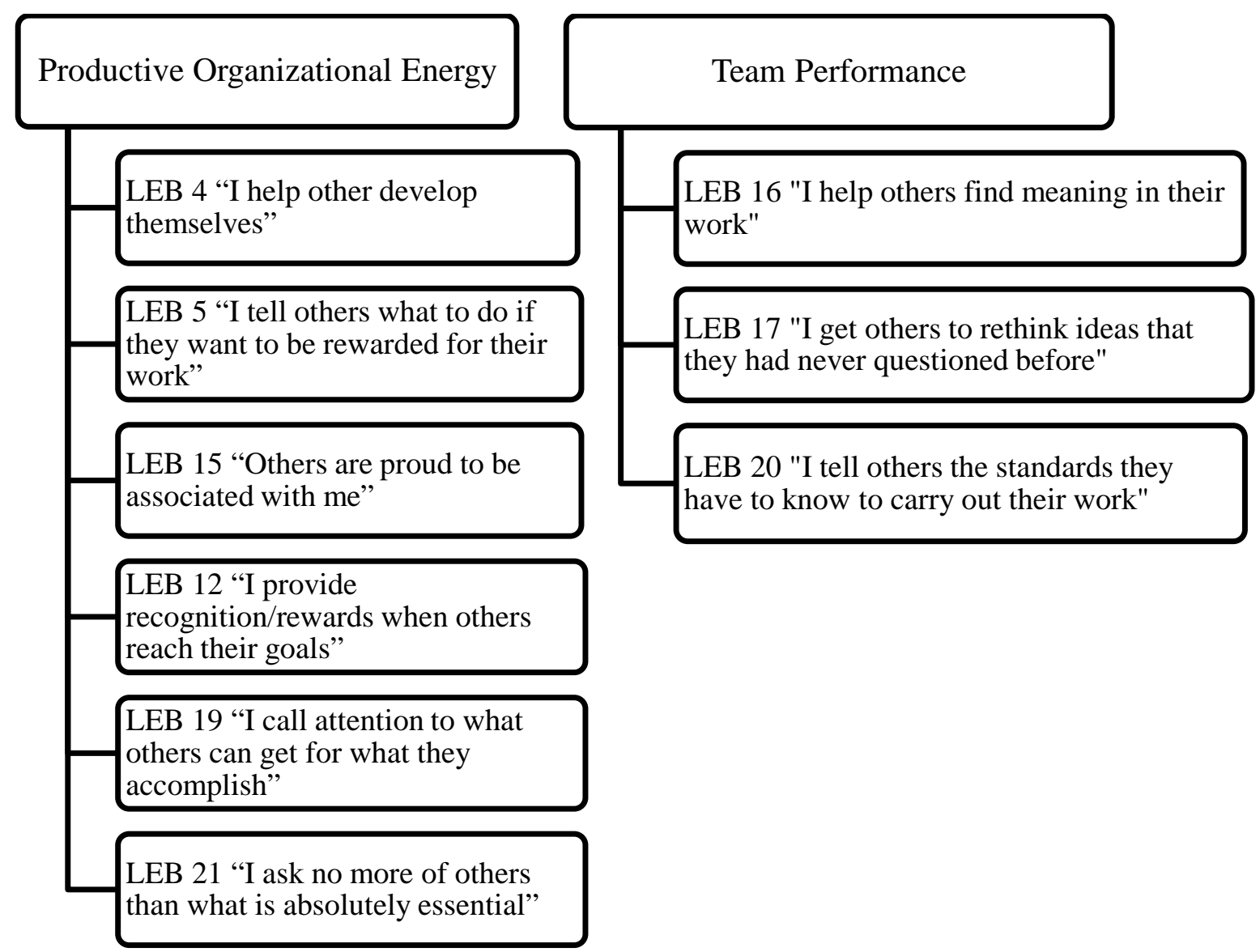

Figure 2 Summary of Leadership Behaviours that Have Positive Impact on Productive Organization Energy and Team Performance (developed by the author) 
There is a positive correlation between POE and team performance of followers $(\mathrm{r}=0.710, \mathrm{p}<0.001)$. It means that higher organizational energy is significantly and positively related to team performance and can be expected higher performance if higher energy is presented. Based on correlation results some leadership behaviours are related to team performance, but most of them are related to productive organization energy (Figure 2).

Research question 3: Which development behaviours of transformational leadership can create and sustain productive organisation energy and team performance?

In summary, leaders `interviews and case studies were highlighted leaders' behaviors that create and sustain productive organizational energy and increase team performance:

- $\quad$ to enhance motivation, morale and inspiration in the organization;

- $\quad$ help to connect employee's sense of identity to team performance;

- $\quad$ improve relation energy in the organization;

- being a role model for followers to inspire them and to raise their interest in organizational mission and vision;

- challenging followers to take greater ownership for their work, and improve job satisfaction;

- understanding the strengths and weaknesses of employees and all team, help to avoid burnout, fatigue and disappointed.

Leaders of organizations relate the human energy to important managerial concerns as team performance, innovation, employee motivation and job satisfaction.

\section{Conclusions}

The theoretical literature analysis and the empirical research performed in this study have allowed drawing the following conclusions.

"Model of Human Energy" in the organization is important for: (1) the ability to maintain personal human energy and to use it correctly for leadership at the workplace, (2) the capacity to increase relational energy as an essential tool for managing the pedagogical process, (3) the possibility to growth productive team energy and (4) the opportunity to rise productive organizational energy.

Transformational leadership as development tool in educational institution will foster a community, provide intellectual stimulation, offer individualizes support, model best practices and value, demonstrate high-performance expectations and create a productive teaching culture, also provide an environment that foster the creation of new and innovative instructional techniques. The skills required for transformational leader need to be identified 
and trained to perform them, incentives must be clarified and implemented to keep followers motivated and inspired.

The results of the empirical study demonstrate that correlation between team performance and productive organization energy of followers is significant and strong. It means that higher organizational energy is significantly and positively related to team performance and expected higher performance if higher energy is present. According to correlation results, leadership factor as "Contingent reward" has a positive impact on productive organizational energy and team performance.

The results of the study can be used to assist and help organizations in identifying practices, processes and initiatives which can have a positive impact on organizational energy and team performance.

\section{References}

Adams, C. M., Olsen, J. J., \& Ware, J. K. (2017). The school principal and student learning capacity. Educational Administration Quarterly, 53(4), 556-584.

DOI: https://doi.org/10.1177/0013161X17696556

Baker, W. E. (2019). Emotional Energy, Relational Energy, and Organizational Energy: Toward a Multilevel Model. Annual Review of Organizational Psychology and Organizational Behavior, 6, 373-395. DOI: https://doi.org/10.1146/annurev-orgpsych012218-015047

Bass, B. M. (1998). Transformational leadership: Industrial, military, and educational impact, 54-69. Mahwah, NJ: Lawrence Erlbaum Associates.

Carmeli, A., \& Spreitzer, G. M. (2009). Trust, Connectivity, and Thriving: Implications for Innovative Behaviors at Work. Journal of Creative Behavior, 43(3), 169-191.

Cole, M. S., Bruch, M. H., \& Vogel, B. (2008). Productive energy in the workplace: a measurement validation and linkage to collective outcomes, 82-95. New York: Fort Worth, TX. DOI: https://doi.org/10.1002/job.759

Freudenberger, H. J. (1975). The staff burn-out syndrome in alternative institutions. Psychotherapy; Theory, Research and Practise, 12(1), 73-82. DOI: https://doi.org/ 10.1037/h0086411

Eisenberg, A., Ignatjeva, S., Iliško, Dz., \& Rauckiene-Michaelsso, A. (2018). Adaptation of the organizational learning culture (OLC) dimension methodology in the Israeli local authorities context. Discourse and Communication for Sustainable Education, 9, 91-112. DOI: https://doi.org/10.2478/dcse-2018-0004

Helou, M. E., \& Nabhani, M. (2016). Teachers' views on causes leading to their burnout. School leadership and Management, 36(5), 1-17. DOI: https://doi.org/10.1080/13632434. 2016.1247051

Jacobson, D. A. (2016). Causes and Effects of Teacher Burnout. Walden University. Dissertations and Doctoral Studies Collection at Scholar Work. Retrieved from https://scholarworks.waldenu.edu/dissertations/2835

Kenny, V., \& Nnamdi, S. (2019). Employee productivity and organizational performance: A theoretical perspective. Retrieved from https://mpra.ub.uni-muenchen.de/93294/

Khumalo, S. S. (2019). The Role of Transformational School Leadership in Promoting Teacher Commitment: An Antecedent for Sustainable Development in South Africa. Discourse 
SOCIETY. INTEGRATION. EDUCATION

Proceedings of the International Scientific Conference. Volume VI, May $28^{\text {th }}-29^{\text {th }}$, 2021. 336-346

and Communication for Sustainable Education, 10(2). 22-32. DOI: 10.2478/dcse-20190015

Leme, A., \& Maia, I. (2015). Evaluation of fatigue at work in teachers using modern resources in the classroom. ScienceDirect, Procedia Manufacturing, 3, 4852-4859. DOI: https://doi.org/10.1016/j.promfg.2015.07.601

Lexico. (2021). Oxford English and Spanish Dictionary, Thesaurus, and Spanish and English Translator. Retrieved from https://www.lexico.com/definition/energy

Leithwood, K., Tomlinson, D., \& Genge, M. (1996). Transformational School Leadership. International Handbook of Educational Leadership and Administration, 1, 785-840. DOI: https://doi.org/10.1007/978-94-009-1573-2_23

Luthans, F., \& Avolio B. J. (2009). The "point” of positive organizational behaviour. Journal of Organizational Behaviour, 30(2), 291-307. DOI: https://doi.org/10.1002/job.589

Masiliauskienė, E., \& Lenkauskaitè, J. (2020). (Re)constrution of the educational experience in future teachers' visios of their professional activity. SOCIETY. INTEGRATION. EDUCATION, Proceedings of International Scientific Conference, 2, 77-86.

Retrieved from:http://journals.rta.lv/index.php/SIE/article/view/5101

Rich, B. L., LePine, J., \& Crawford, E. R. (2010). Job engegament: Antecedents ands effects in job perdomance. Academy of Management Journal, 53, 617-635. DOI: https://doi.org/10.5465/amj.2010.51468988

Rowold, J. (2005). Multifactor Leadership Questionnaire. New York: Mind Garden, Inc. Retrieved from http://www.mindgarden.com/documents/MLQGermanPsychometric.pdf

Ryan, R. M., \& Frederick, C. M. (1997). On energy, personality and health: Subjective vitality as a dynamic reflection of well-being. Journal of Personality, 65, 529-565. DOI: https://doi.org/10.1111/j.1467-6494.1997.tb00326.x

Schwartz, T., Gomez, J., \& McCarthy, C. (2010). The Way We're Working Isn't Working: The Four Forgotten Needs that Energize Great Performance, 67-74. New York: Free Press.

Sun, W., Xu, A., \& Shang, Y. (2014). Transformational leadership, team climate, and team performance within the NPD team: Evidence from China. Asia Pacific Journal of Management, 31, 127-147. DOI: https://doi.org/10.1007/s10490-012-9327-3

Simane, M. (2019). Sustainable education on the example of establishment of Czech Primary minority Schools in interwar Czechoslovakia. Discourse and Communication for Sustainable Development, 10(1), 91-112. DOI: https://doi.org/10.2478/dcse-2019-0008

Swaen, B. (2015). Conceptual framework: Mediating variables. Retrieved from https://www.scribbr.com/dissertation/mediator-variables/

Whetten, D.A., \& Cameron, K.S. (2002). Developing management skills Upper Saddle River, 5 dn edition. New York: Prentice-Hall. 